\title{
New Rangeland Residents in Wyoming? A Survey of Exurban Landowners
}

\author{
Rachel D. Mealor, ${ }^{1}$ Paul J. Meiman, ${ }^{2}$ Ann L. Hild, ${ }^{3}$ David T. Taylor, ${ }^{4}$ and Jennifer S. Thompson ${ }^{5}$ \\ Authors are ${ }^{1}$ Extension Range Specialist, ${ }^{3}$ Professor, Renewable Resources Department, ${ }^{4}$ Professor, Agricultural and Applied Economics Department, \\ and ${ }^{5}$ Small Acreage Coordinator, Cooperative Extension Service, University of Wyoming, Laramie, WY 82071, USA, and ${ }^{2}$ Assistant Professor, \\ Department of Forest Rangeland and Watershed Stewardship, Colorado State University, Fort Collins, CO 80523, USA.
}

\begin{abstract}
Rapid conversion of rural land to exurban development and the ensuing impacts on natural resources have been welldocumented, but information about exurban landowners is lacking. To address this knowledge gap, we surveyed exurban landowners in six Wyoming counties and documented demographic characteristics, motivations, knowledge, and attitudes about natural resources and land management. The overall response rate was $55.6 \%$. Generally, respondents were of retirement age, had lived in Wyoming for about $13 \mathrm{yr}$, and were raised in areas with a population $<10000$. Wyoming respondents lived in exurbia for the lifestyle and aesthetic values and did not expect economic gains from their property. Most respondents had knowledge about, and interest in, invasive species, water quality, landscaping, and gardening. More than half of respondents $(54 \%)$ had never looked for information regarding land management. Information from this study can be used to strengthen the development and delivery of educational programs. Programs that focus on water quality or weed control likely will appeal to more exurban landowners than those that focus solely on grazing management. Our findings provide an accurate characterization of this audience and their motivations and attitudes regarding land management, and suggest that using a multipronged approach for outreach efforts, which includes both cost- and time-efficient ways to conduct important land management practices, might increase participation in educational programs.
\end{abstract}

\section{Resumen}

La rápida conversión de tierras rurales al desarrollo ex urbano y el impacto consiguiente sobre los recursos naturales han sido bien documentados. Sin embargo, no se tiene información sobre los propietarios ex urbanos. Para responder a esta limitación, se hizo una encuesta a propietarios ex urbanos en seis condados de Wyoming y se documentaron las características demográficas, motivaciones, conocimientos, y actitudes sobre recursos naturales y el manejo de la tierra. La tasa de respuesta fue de un 55.6\%. Generalmente los que respondieron fueron personas jubiladas que habían vivido en Wyoming por cerca de 13 años, y habían crecido en áreas con una población de $<$ de 10000 . Las personas que respondieron viven en áreas ex-urbanas por la forma de vida y los valores estéticos y no esperan una ganancia económica por su propiedad. La mayoría de los que respondieron tenían conocimiento e interés en relación a las especies invasivas, calidad del agua, jardinería, y paisaje. Más de la mitad (54\%) de los que respondieron nunca habían buscado información en relación al manejo de la tierra. La información de este estudio puede utilizarse para desarrollar y fortalecer programas educacionales. Dichos programas pueden enfocarse en la calidad del agua o control de malezas y no solamente al manejo del pastoreo. Nuestros resultados caracterizan a este tipo de población, sus motivaciones y actitudes en relación al manejo de la tierra. En consecuencia, se sugiere que usando un acercamiento múltiple que se enfoque en el costo y uso del tiempo en prácticas eficientes de manejo de la tierra, puede dar como resultado que se incremente la participación de los programas educativos.

Key Words: attitudes, education, land management, outreach, water quality, weed control

\section{INTRODUCTION}

The American West is experiencing significant turnover in the ownership of private ranchland (Gosnell and Travis 2005), leading many researchers to ask who will replace today's aging

Research was funded in part by the University of Wyoming Renewable Resources Dept, Wyoming National Agricultural Statistics Service, Audubon Wyoming, the Wyoming Business Council, the Small Acreage Issue Team, University of Wyoming Cooperative Extension Service, University of Wyoming Agricultural and Applied Economics Dept, and Western Regional Sustainable Agricultural Research and Education.

At the time of the research, Mealor was a research assistant, Renewable Resources Dept, University of Wyoming, Laramie, WY 82071, USA.

Correspondence and current address: Rachel D. Mealor, Renewable Resources Dept, University of Wyoming, Dept 3354, 1000 E University Ave, Laramie, WY 82071, USA. Email: rdmealor@uwyo.edu

Manuscript received 23 August 2009; manuscript accepted 19 May 2011. ranchers, and how land management choices will be made (Forero et al. 1992; Gosnell and Travis 2005; Brunson and Huntsinger 2008). Exurban areas, defined as $0.7-16.2$ ha (1.7$40 \mathrm{ac}$ ) per housing unit (Theobald 2003), are the most rapidly growing type of residential development in the United States (Crump 2003). Exurban development is expected to increase by $14.3 \%$ in the next decade, whereas urban and suburban housing is expected to expand by only $2.2 \%$ (Theobald 2005). The rapid pace of exurban development suggests that small exurban properties increasingly could replace larger traditional ranches and become the dominant property type in rural areas located near cities and towns. If ranchlands are to be maintained as valuable economic, cultural, and ecological landscapes, the role of new exurban residents in sustaining the rangeland landscape should be documented (Gosnell and Travis 2005). Exurban development often occurs near protected lands intended to conserve natural resources and biodiversity, and should be 
critically evaluated because of this close proximity to protected habitats (Theobald 2005). Exurban areas support higher levels of nonnative and human-commensal species (Maestas et al. 2003), perhaps at the expense of other native species, and could increase the likelihood of invasion of protected areas surrounding exurban developments. Given the rapid pace at which exurban development is occurring, and the potential impacts of exurban landowners' management decisions on the rangeland resource, it is important to assess the perceptions and attitudes held by such landowners.

Although exurban landowners are becoming more prevalent throughout the Mountain West, limited research describes these individuals and why they choose to live in exurban areas (Nelson 1992). Numerous factors impact rural regions, including humanenvironment relationships and changing social values; unfortunately neither of these has been adequately studied (Nelson 2002). As with management of federal rangelands, ensuring successful management of private, exurban rangelands will require an understanding of beliefs and attitudes (Brunson and Steel 1996). The concept of attitudes or the positive or negative judgments regarding specific ideas or behaviors includes various types of evaluative views such as perceptions of the environment, opinions, and preferences (Trafimow 2000; Decker et al. 2004). Even though documenting attitudes might not allow us to predict every behavior, attitudes do indicate willingness to adopt land management practices (Fernandez-Gimenez et al. 2005). By assessing exurban landowner attitudes, we more clearly can envision their management strategies, willingness to participate in educational programs, and their potential impacts on rangelands. Natural resource advisors working with exurban landowners are interested in methods for effectively sharing information with this audience, but might be uncertain how to approach such interactions. A Natural Resources Conservation Service district conservationist who was surveyed as part of a related study said, "I believe there is a group of exurban landowners who do or would care about natural resource issues, if we could figure out how to reach them."

We know little about exurban landowners, but some general predictions have emerged based on the few studies in the primary literature. Suggestions persist that these landowners arrived in rural areas from out-of-state and have an amenityoriented viewpoint (Brown and Harris 1992; Rudzitis and Streatfield 1992; Gosnell and Travis 2005; Lage 2005). High Country News reports that exurban landowners embrace the idea of being close enough to civilization to get Domino's pizza, but far enough from neighbors to enjoy privacy (Best 2005). Another common and testable assumption is that many exurban landowners keep horses on their property (Nelson 1988; Maestas et al. 2002; Hansen et al. 2005), and a majority $(72 \%)$ of exurban homeowners had at least one grazing animal in a Colorado study (Maestas et al. 2003). Negative impressions associated with improper grazing management perceived by land management educators subsequently are developed in outreach materials. A more reliable description of exurban landowners is actively being sought to provide a solid foundation for outreach efforts because the generalizations that currently are used or highlighted here might not accurately represent the entire exurban clientele.

Many of our predictions resulted from a study on Colorado and New Mexico exurban landowners with 8.1-20.2 ha
(20-50 ac) who lived in close proximity to a national forest boundary. Although this landowner group differed slightly from ours, results indicated such landowners were at least $50 \mathrm{yr}$ old, well-educated, with over half earning an annual income of at least $\$ 60,000$, had resided in exurbia for $10 \mathrm{yr}$ or less, and had urban backgrounds (Shinderman 2004). Our predictions regarding age and motivations for purchasing exurban land were developed based on previous studies which found that older residents valued environmental quality and amenity factors more often than did younger residents (Rudzitis and Streatfield 1992).

Our objectives were to determine the following for exurban landowners in Wyoming: 1) demographic characteristics; 2) land management motivations, priorities, and behavior; and 3) knowledge of, attitudes about, and information needs regarding natural resource management. We predicted that $50 \%$ or more of such landowners are at least $50 \mathrm{yr}$ of age, have lived in Wyoming $<5 \mathrm{yr}$, and moved to Wyoming from other states. We anticipated that a majority of exurban landowners were raised in an urban setting with no previous land management experience and that they had never actively sought information regarding land and natural resource management. We expected that when asked to consider major motivations for purchasing exurban property, exurban landowners would rate aesthetics and open space as more important than economic gain from the land. We anticipated that at least half of these landowners would prioritize land conservation over agricultural production. Finally, given the common generalization that exurban parcels are horse "ranchettes," we predicted that more than two-thirds of exurban landowners keep horses on their property.

\section{METHODS}

Urban and suburban areas are generally defined as parcels smaller than 0.8 ha (2 ac) per housing unit (Theobald 2003). For the purposes of this research, we consider exurban landowners as those who own 0.8 to 16.2 ha of land regardless of socioeconomic status (Theobald 2003).

In August 2006, a mail survey was sent to 4800 Wyoming exurban landowners. Samples were selected from 6 of Wyoming's 23 counties. Such landowners included in the sample frame were individuals who owned and made management decisions on parcels of land between 0.8 and 16.2 ha in size, located in Albany, Campbell, Fremont, Laramie, Sublette, and Teton counties. The total population of exurban landowners in all six counties was 14299 individuals. The six counties were selected to represent the variety of exurban landowners throughout the state, based on the major components of Wyoming's economy. Campbell and Sublette counties' economies are driven by mineral and natural resource extraction, whereas Albany and Laramie counties are supported primarily by government and service industries. Fremont and Teton counties gain much of their income from natural amenity and tourist activities. The survey sample was obtained from the Wyoming Department of Revenue by the Wyoming field office of the US Department of Agriculture National Agricultural Statistics Service (NASS). Eight hundred landowners were selected randomly in each county from landowner lists provided by Wyoming NASS. 
Before mailing the survey, the research plan was sent to the University of Wyoming Institutional Review Board for approval and verification of ethical human research. The mail survey was conducted using a slight modification of the Tailored Design Method (Dillman 2000). A four-part process, including four separate mailings, is recommended to yield a $50-60 \%$ response rate (Salant and Dillman 1994). For this study we used three of the four parts, excluding the prenotice letter. The first mailing was sent out on 29 August 2006. Nine days later, follow-up contacts were implemented because response rates are usually around 20-40\% without them (Dillman 2000). A postcard was sent on 7 September 2006 as a thank-you to the respondents who already had returned their completed surveys and as a reminder to those who had not yet responded. On 18 September 2006 a third mailing was sent to nonrespondents. This mailing included a replacement survey and a letter informing individuals that a completed survey had not been received. Responses to the survey were accepted for analysis until 31 October 2006. The Tailored Design Method (Dillman 2000) recommends a final effort to obtain a response, either by telephone or special mail. Our final effort to obtain responses involved phoning nonrespondents. Contacting nonrespondents increases the validity of studies by gathering data from individuals unwilling to fill out the mail survey (Dillman 2000). Nonrespondents were identified as those within the sample who had not responded to the mail questionnaire as of 26 September 2006. Between 26 September and 7 October 2006, we contacted $23 \%$ of the nonrespondents, who were randomly selected from the list of all nonrespondents. The entire survey was administered to these individuals over the phone, requesting the same information as was requested in the mail survey. A nonresponse analysis enables the investigator to assess whether the respondents accurately represent the sampled population.

\section{Survey Instrument}

The survey consisted of four sections with a total of 39 questions. One section of the survey was developed to determine descriptive demographic characteristics of respondents, such as age, education, length of time at their current exurban residence, the number of acres owned or managed, rural land management experience, and the setting in which they were raised. Another section assessed how exurban landowners make land management decisions with questions about their motivations and attitudes toward natural resources based on a Likert scale $(1=$ not important to $5=$ very important). The survey included questions about the choice to live in the rural West, the importance of land ownership, and knowledge and attitudes about natural resource topics (e.g., invasive weeds, grazing management, wildlife habitat).

The survey included multiple-choice questions and scaled questions. Exurban landowner behavior was assessed by asking which land management practices they implement. Landowner knowledge was assessed by providing respondents with factual statements that are well-supported or widely accepted and asking for their level of agreement on a Likert scale. Color photographs of four weed species were inserted into the questionnaire and exurban landowners were asked to choose the correct name for each weed in multiple-choice questions. We also asked whether or not respondents had looked for information on land management. Respondents who had looked for land management information were asked to rank the top three sources from a list of nine. The survey instrument was tested on a pilot sample 2 mo prior to mailing.

\section{Data Analysis}

Data from telephone interviews were used to perform a nonresponse bias analysis. We tested for differences between mail respondents and telephone respondents by comparing questions about age, highest level of education, annual household income, and where individuals were raised. The nonresponse bias analysis was conducted using cross tabulations to compare responses from the mail questionnaire to answers given via nonrespondent telephone interviews. This comparison suggested that both groups responded similarly to the questions and that individuals who responded to the mail survey did not represent a different group than those who participated in the telephone survey. Therefore, the responses from the mail survey and telephone survey were combined for analysis.

Data were entered into a Survey Management System and analyzed using the Statistical Package for the Social Sciences (version SPSS 14.0). Descriptive statistics and frequencies were calculated for all responses, which included many of the general characteristics of landowners and their parcels of land along with responses to questions regarding knowledge and opinions of natural resource topics. Means and 95\% confidence intervals (CI) were calculated to summarize the data. CI for frequency response variables were calculated as described in Mendenhall and Reinmuth (1982). We also assessed the distribution of the datasets. Where necessary, medians and modes are reported in addition to means to facilitate interpretation of datasets with skewed or bimodal distributions.

\section{RESULTS}

The overall response rate was $55.6 \%$ for mail and telephone surveys combined. Seventy-seven percent of the responses came by mail and $23 \%$ were completed on the telephone. The data collected through the mail survey did not appear to be a biased data set, due to the absence of statistical differences between responses to the demographic questions from the mail and telephone surveys (Lambert and Harrington 1990). Eighteen percent of the 14299 total exurban landowners in the six counties responded to the survey either by mail or telephone. Not all questions were answered by every respondent, resulting in different response rates for different questions. However, all questions received at least 1696 responses.

\section{Respondent Characteristics}

Eighty-four percent of survey respondents were between 30 and $69 \mathrm{yr}$ of age, and $66 \%$ were over $50 \mathrm{yr}$ of age. On average, respondents had some college training, and many earned a graduate degree. The majority of respondents were raised in areas with $<10000$ residents and only $17 \%$ were raised in towns or cities with a population of 50000 or greater. The 
Table 1. Exurban landowners' responses to demographic questions in a survey circulated August through October 2006. Respondents are Wyoming residents who own 0.8 to 16.2 ha of land.

\begin{tabular}{lcc}
\hline $\begin{array}{l}\text { Question } \\
\text { Age of exurban landowner respondent }(n=2323):\end{array}$ & $\begin{array}{c}95 \% \text { Confidence } \\
\text { Interval }\end{array}$ \\
$<30$ yr old & 3 & $0-3$ \\
$30-49$ yr old & 31 & $29-33$ \\
$50-69$ yr old & 53 & $51-55$ \\
$\geq 70$ yr old & 13 & $11-14$
\end{tabular}

Highest level of education for exurban landowner respondent $(n=2320)$ :

$\begin{array}{lcc}\text { Some college, not 4-yr degree } & 28 & 26-30 \\ \text { Bachelor's degree } & 24 & 22-26 \\ \text { Graduate degree } & 23 & 21-25 \\ \text { High school diploma } & 16 & 14-17 \\ \text { Technical school } & 7 & 6-8 \\ \text { Did not complete high school } & 2 & 1-2\end{array}$

Setting where raised for exurban landowner respondent $(n=2322)$ :

$\begin{array}{lrc}\text { Large metro/urban area }(>100000) & 12 & 10-13 \\ \text { Metro/urban area }(50000-99999) & 5 & 4-6 \\ \text { City }(20000-49999) & 12 & 11-14 \\ \text { Small city }(10000-19999) & 9 & 8-10 \\ \text { Small town }(<10,000) & 21 & 19-23 \\ \text { Outside of town (nonfarm) } & 16 & 14-17 \\ \text { Farm or ranch } & 24 & 22-25\end{array}$

Approximate annual household income for exurban landowner respondent $(n=2125)$ :

$\begin{array}{lcc}<\$ 20000 & 5 & 4-6 \\ \$ 20000-\$ 39999 & 13 & 12-15 \\ \$ 40000-\$ 59999 & 19 & 17-21 \\ \$ 60000-\$ 79999 & 21 & 19-22 \\ \$ 80000-\$ 99999 & 15 & 14-17 \\ \geq \$ 100,000 & 26 & 24-28\end{array}$

minority of respondents reported that their approximate annual household income was $\$ 100000$ and above (Table 1). Respondents tended to be more involved in environmental or conservation $(31 \%)$ and youth $(28 \%)$ organizations compared with agricultural $(19 \%)$ and civic $(18 \%)$ organizations.

On average, exurban landowners owned 4.5 ha $(95 \%$ $\mathrm{CI}=4.29-4.61 \mathrm{ha} ; n=2361)$ and had owned or managed their land for $13 \mathrm{yr}(95 \% \mathrm{CI}=12.5-13.5 \mathrm{yr}$; range $=1-85 \mathrm{yr}$; $n=2341)$. Land ownership data are slightly skewed toward longer duration of ownership, so both mean (13-yr) and median (10-yr) scores were reported. Thirty percent of respondents had owned or managed their land for $5 \mathrm{yr}$ or less, whereas $80 \%$ had owned or managed their land for $21 \mathrm{yr}$ or less. Approximately $20 \%$ of respondents had owned or managed their land between 22 and 85 yr. Ninety-six percent of the respondents purchased their property for reasons other than development, and $81 \%$ were full-time residents. When asked where they lived before moving to their current exurban residence, $56 \%$ of respondents stated that they moved from somewhere else in Wyoming, and $43 \%$ of respondents stated that they moved from a residence that was outside city or town limits.

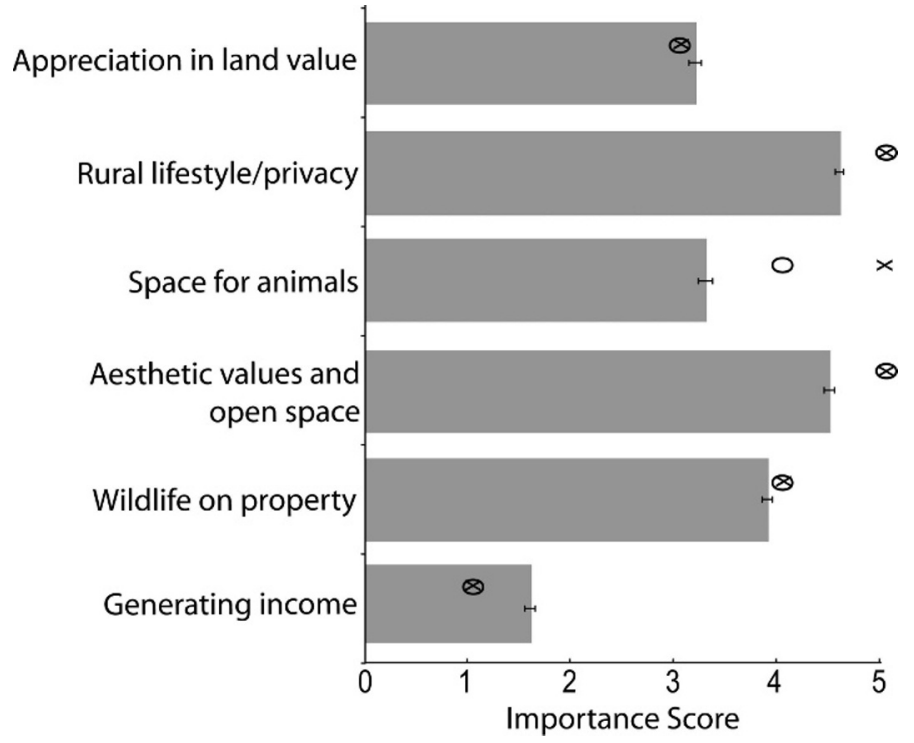

Figure 1. Importance of reasons for purchasing exurban land as rated by exurban landowners in Wyoming ( $5=$ very important, $4=$ important, $3=$ neutral, $2=$ somewhat important, $1=$ not important). 0 indicates median; X, mode; and error bars represent 95\% confidence intervals of each mean. Respondents are Wyoming residents who own 0.8 to 16.2 ha of land.

Sixty percent of respondents indicated that they had no experience managing land prior to the purchase of the property where they lived at the time of the survey. Of the $40 \%$ that did have experience, $24 \%$ previously managed 0.81 or more ha of land and $14 \%$ had experience on a farm or ranch. Few respondents gained their experience from college training in land management $(4 \%)$ or a career in land or natural resource management $(3 \%)$, and only $3 \%$ selected "other experience." The sum of these responses for the different land management experience types exceeded $100 \%$ because respondents could select multiple responses.

Ninety-six percent of respondents reported that $<10 \%$ of their household's total annual income was generated from activities on their property. Fifty-eight percent of exurban landowners obtained their annual income from employment outside of the home (i.e., employment in service industries, federal government, and mineral extraction) and $31 \%$ obtained income from employment in the home (i.e., investment income and retirement). Only $1 \%$ of respondents obtained their annual income from agricultural production, and $11 \%$ selected "other" as a source of income.

When asked if there were horses or other livestock on their private property in 2006, 67\% reported there were none. Of the $33 \%$ of respondents that had livestock on their property, $80 \%$ had horses or mules.

\section{Exurban Landowners' Motivations, Priorities, and Behavior}

Enjoyment of the rural lifestyle (mean $=4.6$; 95\% CI $=4.56-$ $4.64 ; n=2337$ ) and aesthetic values or open space (mean $=4.5$; $95 \% \mathrm{CI}=4.46-4.54 ; n=2330$ ) were the highest-ranked reasons for purchasing exurban parcels (Fig. 1).

When asked about their preference between natural resources on their land and their finances, the majority of respondents $(62 \%)$ stated both should be given equal priority when 
Table 2. Exurban landowners' responses to questions regarding their knowledge and attitudes about land management from a survey circulated August through October 2006. Respondents are Wyoming residents who own 0.8 to 16.2 ha of land.

\begin{tabular}{|c|c|c|}
\hline Question & Response (\%) & $\begin{array}{l}\text { 95\% Confidence } \\
\text { interval }\end{array}$ \\
\hline \multicolumn{3}{|c|}{ Top three sources used to gain information about land management $(n=267$} \\
\hline County Weed \& Pest & 25 & $23-27$ \\
\hline Cooperative Extension Service & 21 & $19-22$ \\
\hline Neighbors, family, or friends & 18 & $16-19$ \\
\hline Conservation districts & 17 & $16-18$ \\
\hline Natural Resources Conservation Service & 7 & $6-8$ \\
\hline Library & 7 & $6-8$ \\
\hline Environmental organizations & 6 & $5-7$ \\
\hline Other & 5 & $4-6$ \\
\hline \multicolumn{3}{|c|}{ Land management information desired or needed $(n=2673)$ : } \\
\hline Weed control & 55 & $53-57$ \\
\hline Landscaping and gardening & 48 & $46-50$ \\
\hline Irrigation & 21 & $19-22$ \\
\hline Animal health and nutrition & 12 & $11-13$ \\
\hline Grazing management & 11 & $10-12$ \\
\hline Business creation/management & 5 & $4-6$ \\
\hline Other & 5 & $4-6$ \\
\hline None & 14 & $13-15$ \\
\hline \multicolumn{3}{|c|}{ Land management practices implemented $(n=2673)$ : } \\
\hline Weed control & 66 & $64-68$ \\
\hline Landscaping and gardening & 62 & $60-64$ \\
\hline Fire prevention & 46 & $44-48$ \\
\hline Creating/improving habitat for wildlife & 28 & $26-30$ \\
\hline Sustainable grazing management & 22 & $20-24$ \\
\hline Other & 4 & $3-5$ \\
\hline None & 5 & 4-6 \\
\hline
\end{tabular}

Things that might hinder the implementation of needed land management practices $(n=2673)$ :

$\begin{array}{lcc}\text { Cost } & 52 & 50-54 \\ \text { Time } & 37 & 35-39 \\ \text { Knowledge } & 36 & 34-38 \\ \text { Physical/other limitations } & 16 & 15-17 \\ \text { Government restrictions } & 14 & 13-15 \\ \text { Other } & 3 & 2-4 \\ \text { Not needed } & 14 & 13-15\end{array}$

Best time of year to attend workshop or educational activity ( $n=2243)$ :

$\begin{array}{lcc}\text { Spring: March-May } & 26 & 24-28 \\ \text { Summer: June-August } & 10 & 9-12 \\ \text { Fall: September-November } & 8 & 7-9 \\ \text { Winter: December-February } & 23 & 21-25 \\ \text { Would not attend } & 32 & 30-34\end{array}$

Best day of the week to attend workshop or educational activity $(n=2194)$ :

$\begin{array}{lll}\text { Weekdays } & 41 & 39-43 \\ \text { Weekend } & 26 & 24-28 \\ \text { Would not attend } & 33 & 31-35\end{array}$

Best time of day to attend workshop or educational activity $(n=2202)$ :

Morning: 0800 hours -1200 hours 29 27-32

Afternoon: 1300 hours-1700 hours $\quad 18 \quad 16-21$
Table 2. Continued.

\begin{tabular}{lcc}
\hline Question & Response (\%) & $\begin{array}{c}95 \% \text { Confidence } \\
\text { interval }\end{array}$ \\
\hline Evening: 1800 hours-2100 hours & 19 & $17-22$ \\
Would not attend & 33 & $31-36$ \\
\hline
\end{tabular}

managing their land. More than a quarter of respondents $(28 \%)$ prioritized natural resources over finances. The most common land management practices implemented by respondents were weed control, landscaping, and gardening (Table 2). Respondents stated that cost, time, and knowledge limitations were the top three reasons for not implementing needed land management practices (Table 2).

\section{Respondent Knowledge, Attitudes, and Preferences About Natural Resources and Land Management}

Respondent reactions to statements about land management are presented in Figure 2a. Overall, respondents agreed with commonly accepted statements regarding land management. One statement in particular yielded a fairly complex set of responses. Respondents were asked if they agreed that $<10 \%$ of the plants introduced to North America from other continents become problematic invasive weeds. The mean response score for this question (Fig. 2a) was driven by the fact that $26 \%$ of respondents disagreed or strongly disagreed with that statement and 14\% selected "neutral." Only 16\% agreed or strongly agreed with this statement and $45 \%$ were unsure.

When asked to identify weed species from color photographs in a multiple-choice format, $64 \%$ of the respondents correctly identified cheatgrass (Bromus tectorum L.). Eighty-seven percent of respondents correctly identified Canada thistle (Cirsium arvense [L.] Scop). Whitetop (Cardaria draba [L.] Desv.) was correctly identified by $46 \%$ of the respondents, and $71 \%$ correctly identified Russian knapweed (Acroptilon repens [L.] DC.).

Self-reported knowledge scores of respondents on a variety of issues were fairly low overall (Fig. 2b). Respondents ranked the spread of invasive weeds, degradation of wildlife habitat, and water pollution as the issues about which they knew the most, but the two issues related to production agriculture had significantly lower scores (Fig. 2b). Respondent concern levels (Fig. 2c) were higher on topics for which their self-reported knowledge scores were higher (i.e., water quality, spread of invasive weeds, and wildlife habitat).

Over half of the respondents (54\%) reported they had never looked for information regarding land management. The $46 \%$ that had looked for information identified county Weed \& Pest programs; the Cooperative Extension Service; conservation districts; and neighbors, family, or friends (Table 2) as the most commonly used information sources. Exurban landowners had given the most consideration to weed and pest control and water rights, which were ranked higher than grazing management and other concerns (Fig. 3). The majority of respondents indicated that they either needed or wanted information about weed control, landscaping, and gardening (Table 2) by selecting these topics from a list. Thirty-one percent of respondents reported they most likely would use a newsletter, 


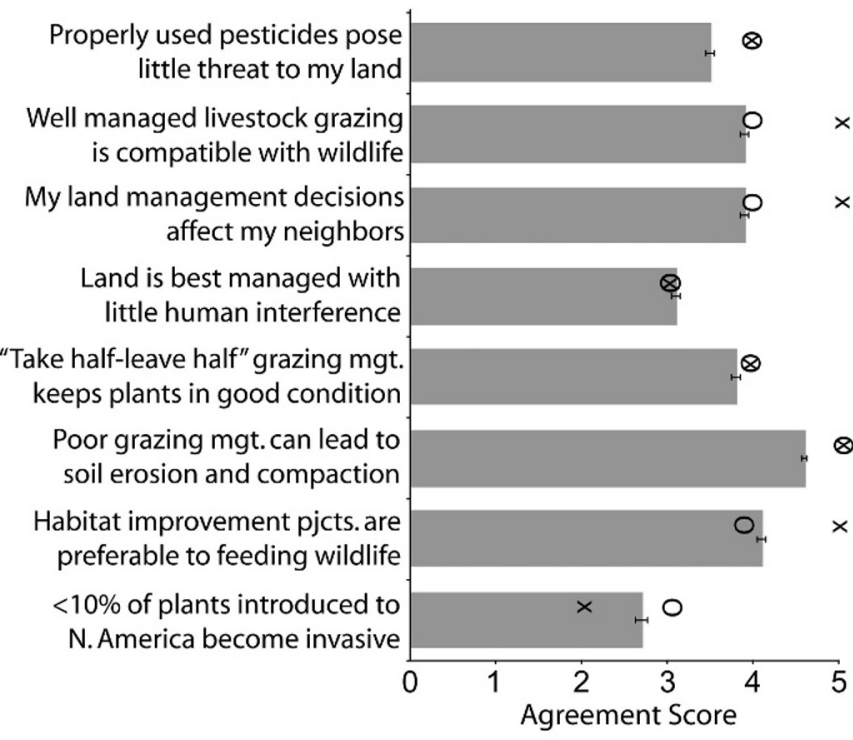

b

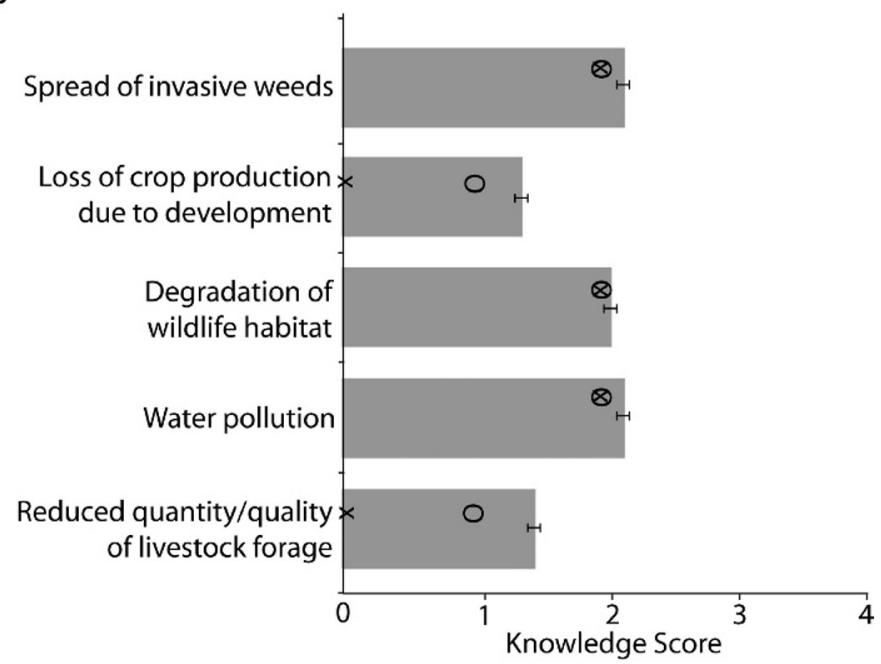

C

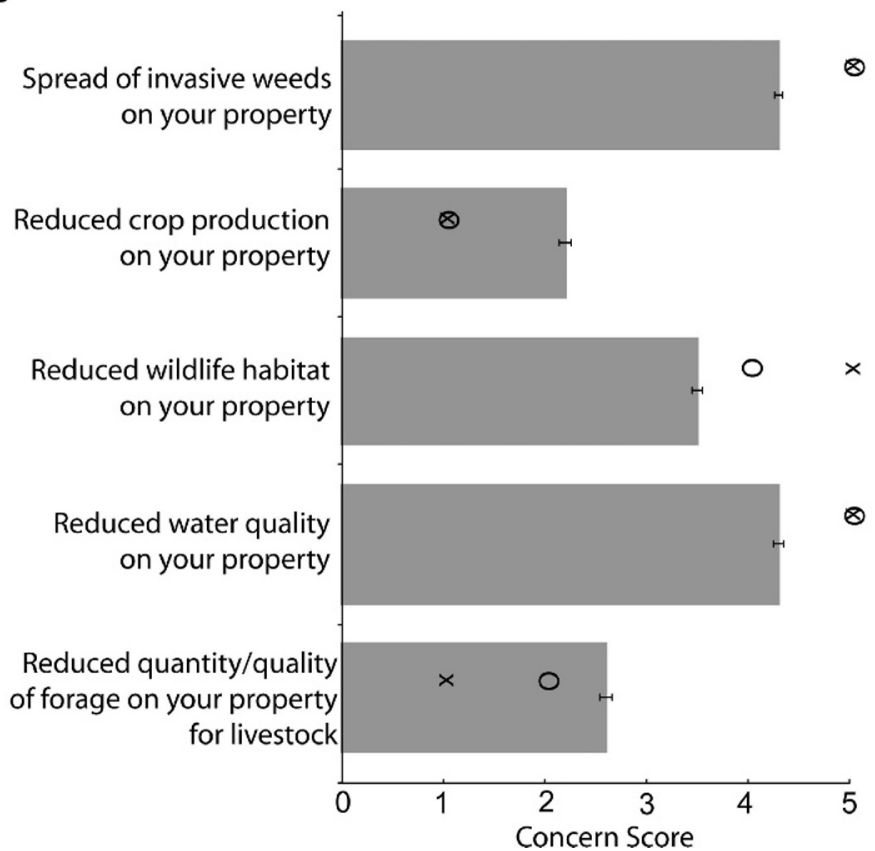

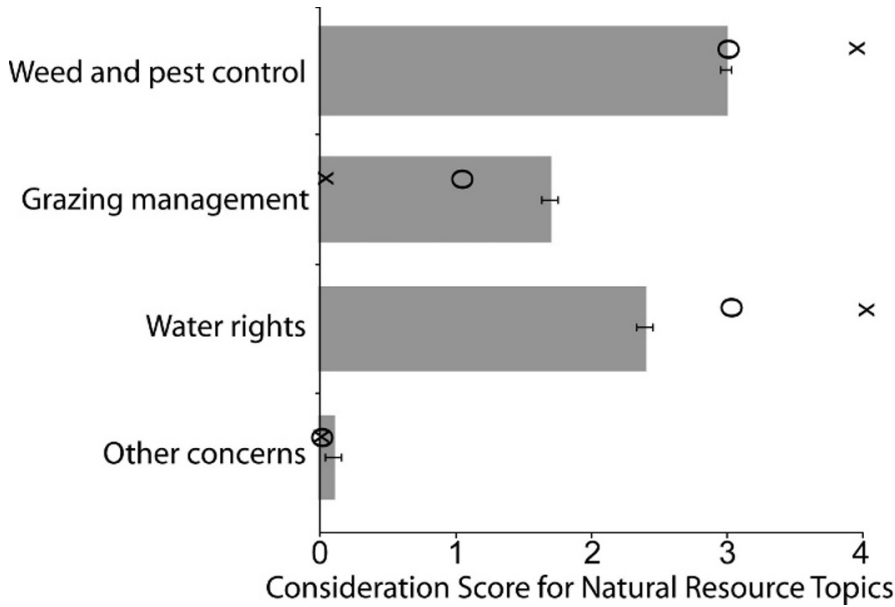

Figure 3. Amount of consideration exurban landowners in Wyoming have given to topics in relation to respondent's private land $(4=\mathrm{a}$ considerable amount, $3=$ a fair amount, $2=$ a moderate amount, $1=\mathrm{a}$ small amount, $0=$ none). 0 indicates median; $X$, mode; and error bars represent $95 \%$ confidence intervals of each mean. Respondents are Wyoming residents who own 0.8 to 16.2 ha of land.

fact sheet, or magazine to obtain information, which ranked higher than internet websites, one-on-one interactions, workshops or field trips, radio or television, and other sources (Fig. 4). Although consistently around $30 \%$ of respondents stated they would not attend a workshop or educational activity, those who would attend selected spring (March-May) as the best time of year. Weekdays were preferred over weekends, and the morning (0800 hours-1200 hours) was identified as the best time of day for workshops (Table 2).

\section{DISCUSSION}

Exurban development continues to affect areas throughout the Mountain West, and likely will expand, bringing about continued change to land management (Esparaza and Carruthers 2000; Theobald 2005). Exurban development has the potential to affect the ecology, economy, and sociology of the West (Jobes 2000; Maestas et al. 2003; Kreuter et al. 2006). Proactive efforts to support management of exurban parcels should be based on accurate characterizations of exurban landowners. If communication programs that demonstrate applicability to real-world issues are assumed to be favored by adults (Toman et al. 2006),

Figure 2. Wyoming exurban landowner level of a, agreement with statements about land management and land management practices ( 5 = strongly agree, $4=$ agree, $3=$ neutral, $2=$ disagree, $1=$ strongly disagree), $\mathbf{b}$, self-assessment of knowledge of land management issues $(4=\mathrm{a}$ considerable amount, $3=$ a fair amount, $2=$ a moderate amount, $1=\mathrm{a}$ small amount, $0=$ none; scale on $\mathrm{y}$ axis adjusted because of low values), and c, level of concern about land conditions ( $5=$ very concerned, $4=$ concerned, $3=$ neutral, $2=$ somewhat concerned, $1=$ not concerned). For all panels, 0 indicates median; $X$, mode; and error bars represent $95 \%$ confidence intervals of each mean. Respondents are Wyoming residents who own 0.8 to 16.2 ha of land. 


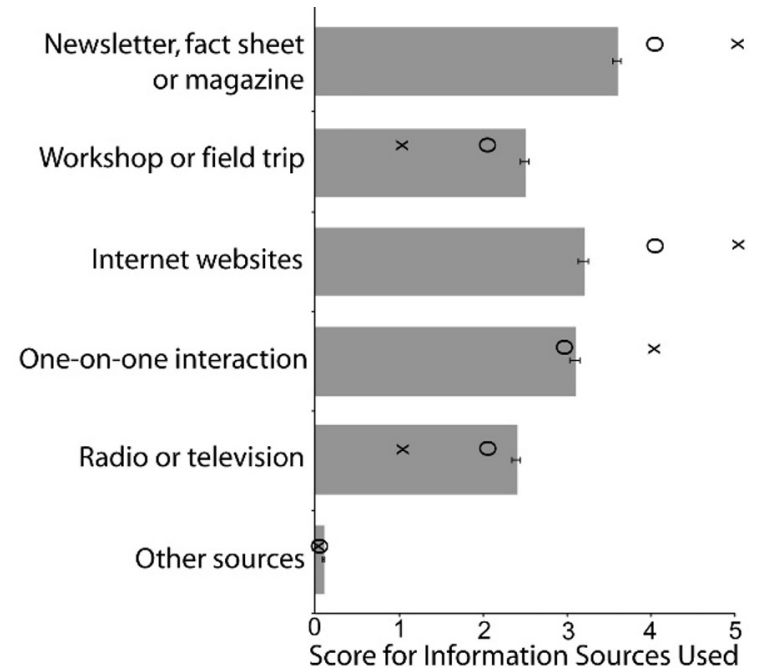

Figure 4. Sources of land management information most likely to be used by Wyoming exurban landowners $(5=$ most likely, $4=$ very likely, 3 = likely, 2 = somewhat likely, $1=$ least likely). 0 indicates median; $X$, mode; and error bars represent $95 \%$ confidence intervals of each mean. Respondents are Wyoming residents who own 0.8 to 16.2 ha of land.

then educators have a responsibility to assess clientele needs and provide information on relevant issues. Once needs are determined accurately, outreach programs should be tailored accordingly to reflect clientele interests. However, another important consideration is how best to disseminate information. A study of county extension agents in Texas assessed an outreach program promoting the use of brush management treatments (Brush Busters; Kreuter et al. 2001). The program's popularity was credited to its low-cost techniques that emphasized effectiveness in the short-term along with the important fact that the information was user-friendly. Information about the program was disseminated using brochures, videos, and field demonstrations (Kreuter et al. 2001).

Extrapolation of our results to the general exurban landowner population might be limited because our respondents were from six Wyoming counties. However, by addressing the issue of effective outreach discussed above, and accurately characterizing our respondents' motivations and attitudes regarding land management, our results highlight critical considerations for providing outreach opportunities to this growing population of landowners.

Although we only surveyed exurban landowners from six counties in Wyoming, it is informative to compare our results with state averages of demographic characteristics. Our prediction regarding age of exurban landowners was supported $(53 \%$ of respondents between 50 and 69 and $13 \% 70+$ yr old) and our respondents were older than the general population of Wyoming (18\% between 55 and 74, and 6\% 75+ yr of age; Wyoming Business Council 2005). Respondent age can be valuable in ascertaining characteristics about an individual. Older individuals are more likely to use newsletters or magazines to gain information and have a stronger value towards environmental quality, whereas younger clientele utilize web-based sources more readily and have less consideration for amenities' values (Rudzitis and Streatfield 1992; R.D. Mealor, unpublished data, 2007).
The assumption that exurban landowners are newcomers who lack land management experience was not supported. Respondents were not as "new to the land" as we predicted. Wyoming exurban respondents had shorter land tenure than that reported for Texas ranchers $($ mean $=19.8 \mathrm{yr}$; Rowan and White 1994) and Arizona permittees (mean $=23$ yr; FernandezGimenez et al. 2005), but not nearly as short as we anticipated. Although the mean tenure of ownerships was lower in our study, the range of tenure responses for Arizona permittees (1-77; Fernandez-Gimenez et al. 2005) is very similar to responses reported here. These results suggest that Wyoming's exurban landowners consist of a mix of relatively new landowners and those with a much longer duration of tenure-a description that easily could be applied to the contemporary ranching population in the region. Thus, ownership tenure of our respondents might be more similar to western ranchers than originally thought.

Our prediction that exurban landowners had moved to Wyoming from urban areas with populations $>50000$ in other states also was inaccurate. Our findings agree with studies in Montana's western valleys that report residents relocating from other counties in the state (Flores 1999). Given the number of Wyoming respondents who originally were from rural Wyoming, we might have underestimated their awareness of, and experience with, natural resource management. Many of our respondents are familiar with Wyoming's landscapes and have rural backgrounds, results that agree with other studies indicating such landowners return to a setting that is similar to their origins because they are attracted to small towns and rural lifestyles (Nelson 1992; Lage 2005).

We correctly predicted that fewer than half of exurban landowners surveyed had looked for information to help them make land management decisions. However, this assumption often is based on the idea that these landowners are unaware of the networks and agencies available to provide such assistance. Our results suggest that exurban landowners have more land management experience than often is assumed, so perhaps they perceive they have sufficient land management knowledge.

As we predicted, Wyoming exurban respondents derive little income from their property. Still, they identify cost as the primary reason for not implementing needed land management practices. Our respondents had a much higher household income than the Wyoming average (in 2005, \$45817; 90\% $\mathrm{CI}=\$ 44000-\$ 46826$; US Census Bureau 2005) and did not purchase their property for profit. The responses reported here suggest that many landowners in today's West have shifted their focus away from production agriculture toward land amenities as reported elsewhere (Gosnell and Travis 2005; Lage 2005).

Enjoyment of a rural lifestyle, aesthetic values, and open space are very important to our Wyoming respondents and consistent with expectations that they desire a rural lifestyle (Rudzitis and Streatfield 1992; Lage 2005). Exurban landowners place very high value on open space, attractive natural environment, and privacy (Crump 2003). However, our respondents did not prioritize natural resources over their finances when making land management decisions. Comparatively, small-acreage ranchers in Texas expressed goals that were noneconomic and dominated by lifestyle choices (Rowan 1994). 
Perhaps the most inaccurate of all generalizations examined in this study relates to horse ownership. The parcels we defined as exurban in this study often are referred to as ranchettes and horse properties (Best 2005). Only one-third of exurban landowners who responded to the survey kept livestock and one-quarter owned horses, in contrast to our prediction. Our results differ greatly from Maestas et al. (2003) who reported in a Colorado study that $72 \%$ of exurban homeowners had at least one grazing animal. Many authors include some reference to horse ownership in the definition of ranchette (Theobald et al. 1996; Jensen 2001; Sengupta and Osgood 2002; Bock et al. 2006), whereas others imply horse ownership or highlight horse-related problems (Nelson 1988; Maestas et al. 2002; Hansen et al. 2005). Although the stereotype of "horse properties" still seems to exist, our data indicate a low occurrence of horse ownership on Wyoming exurban parcels. The mismatch between proportion of grazed properties and perceived management effects might persist because mismanaged properties have a large visual impact on observers, but well-managed properties go unnoticed. In other words, one property overgrazed by horses probably attracts much more attention than several well-managed horse properties. Impressions based on the negative impacts from a few mismanaged properties might be significant enough to drive educational or regulatory efforts targeted at exurban landowners.

Wyoming respondents indicated they are most concerned with acquiring information regarding invasive plant species and their control, water quality, landscaping, and gardening; all consistent with conclusions from Sedman (2004). Given that far less than half of our respondents had horses or other livestock on their property, we cannot assume that improperly managed livestock grazing by the current landowner is the primary cause of exotic invasions or that exurban landowners are poor grazing managers. We documented that many current owners are capable of weed identification, and demonstrate an interest in learning more about invasive species. Water quality was equally important to our respondents, and both areas of instruction should be well-received based on our results. Educational programs focused on grazing management might not be a high priority given our results. Grazing management training, which often is provided to traditional agricultural audiences, might not entice exurban landowner attendance.

Respondent interest in invasive weed control, water quality, landscaping, and gardening suggests a need for increased emphasis on programs related to these topics. If individuals seek information related topics that affect them or areas with which they are concerned (Wondolleck and Yaffee 2000; Shindler et al. 2002), then our results indicate that our exurban respondents might be experiencing weed management or water quality issues. Our respondents might be participating in weed control programs, which could explain their frequent use of county Weed \& Pest Control districts for information and their ability to correctly identify common weed species. It is clear from our results that there is not one preferred method of learning, indicating that a multipronged approach could reach a larger audience. Resource advisors and educators should consider offering information to exurban landowners regarding topics of interest to the audience using unidirectional methods (newsletter/ magazine) along with interactive formats (one-on-one interactions) that can adapt to the interests and concerns of the clientele (Toman et al. 2006). Once clientele needs have been assessed, topics of interest should be incorporated in outreach efforts that ensure diversity with a variety of dissemination methods. As with the Brush Busters program (Kreuter et al. 2001, 2008), educational efforts that are cost- and time-efficient could increase their adoption.

\section{MANAGEMENT IMPLICATIONS}

This study provides the first and most comprehensive description of exurban landowners in Wyoming. The results presented here are directly applicable to the six Wyoming counties surveyed, but offer additional insights and testable predictions that could be important throughout the Mountain West and the entire country.

We encourage natural resource advisors and educators to consider our results when planning outreach programs to better meet exurban landowner needs. By incorporating information shown to be of interest to exurban respondents (i.e., invasive species management, water quality, landscaping, and gardening) into outreach programs, natural resource advisors could attract more exurban clientele and create new opportunities to discuss other important rangeland management topics (e.g., grazing management and wildlife habitat). Developing a strategy to deliver broad-based educational programs, including an array of land management tools, will provide landowners with a better understanding of desired topics and exposure to new management issues. Mode of delivery also is important. How might information successfully be delivered to the $30 \%$ of respondents who would not attend workshops? A multipronged extension effort for our exurban clientele should incorporate print media, online information, mass media, and in-person education. Educators must diversify their outreach efforts to promote more successful transfer of needed natural resources and land management information to these landowners. Most importantly, our study underscores the weakness of generalizations regarding exurban landowners and how such generalizations can result in misdirected outreach efforts. Our results, in concert with prior studies of such landowners, highlight the variability in landowner characteristics and emphasize the value of knowing one's audience.

\section{ACKNOWLEDGMENTS}

We sincerely appreciate all of the support and assistance we received. We thank all the exurban landowners who took time to complete the survey. We greatly appreciate Wyoming NASS for their assistance in implementing the survey. A special thanks to Dr Maria E. Fernandez-Gimenez and Dr Brian A. Mealor for helpful comments on earlier versions of this manuscript and Dr Urs P. Kreuter for thoughts and suggestions regarding the development of survey questions. We also appreciate the thoughtful review and constructive comments from the editors and reviewers.

\section{LITERATURE CITED}

Best, A. 2005. How dense can we be? High Country News 37:10-12.

Bock, C. E., Z. F. Jones, AND J. H. Bock. 2006. Abundance of cottontails (Sylvilagus) in an exurbanizing southwestern savanna. The Southwestern Naturalist 51: 352-357. 
Brown, G., AND C. HaRrIS. 1992. The USDA Forest Service: toward the new resource management paradigm? Society \& Natural Resources 5:231-245.

Brunson, M. W., and L. Huntsinger. 2008. Ranching as a conservation strategy: can old ranchers save the new west? Rangeland Ecology \& Management 61:137-147.

Brunson, M. W., And B. S. Steel. 1996. Sources of variation in attitudes and beliefs about federal rangeland management. Journal of Range Management 49:69-75.

CRUMP, J. R. 2003. Finding a place in the country: exurban and suburban development in Sonoma County, California. Environment and Behavior 35:187-202.

Decker, D. J., T. L. Brown, J. J. Vaske, And M. J. Manfredo. 2004. Human dimensions of wildlife management. In: M. J. Manfredo, J. J. Vaske, B. L. Bruyere, D. R. Field, and B. P. J. [EDS.]. Society and natural resources: a summary of knowledge. Jefferson, MO, USA: International Association for Society and Natural Resources. p. $187-198$.

Dillman, D. A. 2000. Mail and internet surveys: the tailored design method. New York, NY, USA: John Wiley \& Sons. p. 149-193.

Esparaza, A. X., and J. I. Carruthers. 2000. Land use planning and exurbanization in the rural mountain west: evidence from Arizona. Journal of Planning Education and Research 20:23-36.

Fernandez-Gimenez, M. E., S. Jorstad, and G. Ruyle. 2005. Arizona permittee and land management agency employee attitudes toward rangeland monitoring by permittees. Rangeland Ecology \& Management 58:344-351.

FLoRES, D. 1999. In Montana: the view from the ranchette. Available at: http://www. hon.org/servlets/hcn.Article?article_id=4993. Accessed 7 July 2007.

Forero, L., L. Huntsinger, and W. J. Clawson. 1992. Land use change in three San Francisco Bay Area counties: implications for ranching at the urban fringe. Journal of Soil and Water Conservation 47:475-480.

Gosnell, H., and W. R. Travis. 2005. Ranchland ownership dynamics in the Rocky Mountain West. Rangeland Ecology \& Management 58:191-198.

Hansen, A. J., R. L. Knight, J. M. Marzluff, S. Powell, K. Brown, P. H. Gude, and K. JoNES. 2005. Effects of exurban development on biodiversity: patterns, mechanisms and research needs. Ecological Applications 15:1893-1905.

JenSEN, M. N. 2001. Can cows and conservation mix? BioScience 51:85-90.

JoBES, P. C. 2000. Moving nearer to heaven: the illusion and disillusion of migrants to scenic rural places. Westport, CT, USA: Greenwood Publishing Group. $242 \mathrm{p}$.

Kreuter, U. P., H. E. Amestoy, D. N. Ueckert, and W. A. McGinty. 2001. Adoption of Brush Busters: results of Texas county extension survey. Journal of Range Management 54:630-639.

Kreuter, U. P., M. V. Nair, D. Jackson-Smth, J. R. Conner, and J. E. Johnston. 2006. Property rights orientations and rangeland management objectives: Texas, Utah, and Colorado. Rangeland Ecology \& Management 59:632-639.

Kreuter, U. P., J. B. Woodard, C. A. Taylor, and W. R. Teague. 2008. Perceptions of Texas landowners regarding fire and its use. Rangeland Ecology \& Management 61:456-464.

LAGE, J. 2005. Coming into the country: new owners of ranches in the Sierra Valley, California. Available at: http://www.centerwest.org/ranchlands/lage_aag. pdf. Accessed 31 July 2011.

Lambert, D. M., and T. C. HarRington. 1990. Measuring nonresponse bias in customer service mail surveys. Journal of Business Logistics 11:5-25.

Maestas, J. D., R. L. Knight, and W. C. Gilgert. 2002. Cows, condos or neither: what's best for rangeland ecosystems? Rangelands 24:36-42.
Maestas, J. D., R. L. Knight, and W. C. Gilgert. 2003. Biodiversity across a rural land-use gradient. Conservation Biology 17:1425-1434.

Mendenhall, W., and J. E. Reinmuth. 1982. Statistics for management and economics. 4th ed. Boston, MA, USA: Duxbury Press. $902 \mathrm{p}$.

Nelson, A. C. 1988. An empirical note on how regional urban containment policy influences and interaction between greenbelt and exurban land markets. Journal of the American Planning Association 54:178-184.

Nelson, A. C. 1992. Characterizing exurbia. Journal of Planning Literature 6:350-368.

Nelson, P. B. 2002. Perceptions of restructuring in the rural west: insights from the "cultural turn." Society and Natural Resources 15:903-921.

Rowan, R. C. 1994. Are small-acreage livestock producers real ranchers? Rangelands 16:161-166.

Rowan, R. C., AND L. D. WHite. 1994. Regional differences among Texas rangeland operators. Journal of Range Management 47:338-343.

Rudzitis, G., and R. A. Streatfield. 1992. The importance of amenities and attitudes: a Washington example. Journal of Environmental Systems 22:269-277.

Salant, P., and D. A. Dillman. 1994. How to conduct your own survey. New York, NY, USA: John Wiley \& Sons. $138 \mathrm{p}$.

Sedman, J. 2004. Western land small acreage survey analysis. Huntley, WY, USA: Sedman Economics Consulting. p. 1-2.

Sengupta, S., and D. E. Osgood. 2002. The value of remoteness: a hedonic estimation of ranchette prices. Ecological Economics 44:91-103.

Shinderman, M. J. 2004. Exurban land use and landowner perceptions of ecosystem management concepts [dissertation]. Fort Collins, CO, USA: Colorado State University. $96 \mathrm{p}$.

Shindler, B., M. Brunson, and G. H. Stankey. 2002. Social acceptability of forest conditions and management practices: a problem analysis. PNW-GTR-537. Portland, OR, USA: Deparment of Agriculture, Forest Service, Pacific Northwest Research Station. $68 \mathrm{p}$.

Theobald, D. M. 2003. Defining and mapping rural sprawl: examples from the Northwest US. Fort Collins, C0, USA: Growth Management Leadership Alliance white paper. $6 \mathrm{p}$.

Theobald, D. M. 2005. Landscape patterns of exurban growth in the USA from 1980 to 2020. Ecology and Society 10:32-66.

Theobald, D. M., H. Gosnell, and W. E. Riebsame. 1996. Land use and landscape change in the Colorado Mountains II: a case study of the East River Valley. Mountain Research and Development 16:407-418.

Toman, E., B. Shindler, and M. Brunson. 2006. Fire and fuel management communication strategies: citizen evaluations of agency outreach programs. Society and Natural Resources 19:321-336.

Trafimow, D. 2000. A theory of attitudes, subjective norms, and private versus collective self-concepts. In: D. J. Terry and M. A. Hogg [EDS.]. Attitudes, behavior, and social context; the role of norms and group membership. Mahwah, NJ, USA: Lawrence Erlbaum Associates. p. 47-65.

US Census Bureau. 2005. Income of households by State using a 2-yr-average median. Available at: http://www.census.gov/hhes/www/income/income05/ statemhi2.html. Accessed 7 July 2007.

Wondolleck, J. M., And S. L. YaffeE. 2000. Making collaboration work: lessons from innovation in natural resource management. Washington, DC, USA: Island Press. $277 \mathrm{p}$.

Wyoming Business Council. 2005. Wyoming demographics from the 2007 US Census. Available at: http://www.whywyoming.org/demographics.aspx. Accessed 7 July 2007. 